\title{
Description of a new species of Corixidea from Brazil (Heteroptera: Dipsocoromorpha: Schizopteridae)
}

\author{
Fernando da Silva Carvalho-Filho' (1) \& Flavio Albuquerque ${ }^{2}$ (1)
}

\begin{abstract}
1 Coordenação de Zoologia, Laboratório de Entomologia, Museu Paraense Emílio Goeldi (MPEG), Belém, Pará, Brazil. (fernandofilho@museu-goeldi.br) 2 Instituto de Ciências Biológicas, Universidade Federal do Pará (UFPA), Belém, Pará, Brazil. (flavio.heteroptera@gmail.com)
\end{abstract}

Received 5 December 2020

Accepted 30 April 2021

Published 31 May 2021

DOI $10.1590 / 1678-4766 e 2021010$

\begin{abstract}
The minute litter bug genus Corixidea Reuter, 1891 currently comprises nine valid American species. Herein, we describe Corixidea quaresmai sp. nov. from one of the last remaining remnants of Atlantic Forest in northeast Brazil. The new species is characterized by the distal extension of the anophoric process parallel and close to the left lateral margin of the tergites, and the elongated process of tergum 8 , with a pectinate distal half and a filiform tip. We provide diagnosis, images of habitus and male genitalia.
\end{abstract}

KEYWORDS. Atlantic Forest, Neotropical region, Schizopterinae, taxonomy, true bug.

RESUMO. Descrição de uma espécie nova de Corixidea para o Brasil (Heteroptera: Dipsocoromorpha: Schizopteridae). Corixidea Reuter, 1891 compreende atualmente nove espécies válidas registradas para as Américas. No presente estudo, Corixidea quaresmai sp. nov. é descrita de um dos últimos remanescente de Mata Atlântica da região Nordeste do Brasil. A espécie nova é caracterizada pela extensão distal do processo anofórico paralela e próxima à margem lateral esquerda dos tergitos e pelo processo do tergo 8 alongado, com a margem distal pectinada e ápice filiforme. Diagnose, imagens do habitus e da genitália masculina são fornecidas.

PALAVRAS-CHAVE. Mata Atlântica, Região Neotropical, Schizopterinae, taxonomia, percevejo.

Schizopteridae is composed of tiny (body length $\sim 0.8-3.0 \mathrm{~mm}$ ) usually dull colored true bugs that are found mainly in cryptic habitats such as leaf litter, under bark of fallen trees, and forest canopies (EMSLEY, 1969; WeIRAUCH \& ŠTys, 2014; WeIrauch \& Fernandes, 2015; SchuH \& WeIraUCH, 2020). This family is composed of about 60 genera and more than 350 described species distributed in all biogeographic regions, but with the greatest diversity in tropical and subtropical regions (WEIRAUCH \& ŠTYS, 2014; Weirauch \& Fernandes, 2015; SchuH \& Weirauch, 2020).

Despite the remarkable diversity of schizopterid species in the tropical regions, this is one of the least studied groups among Heteroptera. The fauna of schizopterids from Brazil is composed of only 22 species in 13 genera, 11 of which were described in the last four years (HOEY-CHAMBERLAIN \& Weirauch, 2016; KNyshov et al., 2016; Almeida et al., 2019a,b, 2020; SiLVEIRA et al., 2019; WeIRAUCH et al., 2020).

Corixidea Reuter, 1891, one of the genera previously recorded from Brazil, comprises nine described species in the Americas. Corixidea, Hoplonannus McAtee \& Malloch, 1925, Membracioides McAtee \& Malloch, 1925, Oncerodes Uhler, 1849 and Voccoroda Wygodzinsky, 1950 form the group named by EMSLEY (1969) as the Corixidea genus group. Voragocoris Weirauch, 2012 was posteriorly included in the Corixidea genus group (WeIRAUCH, 2012). Recent phylogenetic studies have supported the monophyly of Corixidea genus group (WEIRAUCH \& ŠTYS, 2014; KNYSHOV et al., 2019).This group can be distinguished by the truncate labium, pronotum lacking a pronotal collar, sclerotized costal cells of the hemelytra, and distinct hyperpleural lobes (EMSLEY, 1969).

KNYSHOv et al. (2019) recovered the monophyly of the Corixidea genus group, but the genus Corixidea was paraphyletic. The sampled species of this genus formed two distinct clades, which were named as Corixidea major group and Corixidea crassa group. The former is characterized by a "laterally directed process on tergum 8 and the presence of a serrated area on tergum 8 ", and the latter is composed 
of two subclades, one of them "characterized by the anteriorly directed process of tergum 8 ", and the other by the "combination of a laterally directed process of tergum 8 and the presence of an anophoric process" (KNYSHOV et al., 2019).

During the process of surveying one of the last remaining fragments of Brazilian Atlantic Forest in the northeast region, a new species of Corixidea was found. Given the diagnostic features presented by KNYSHOv et al. (2019) this new species could be allocated in the Corixidea crassa group by the laterally directed process of tergum 8 and the presence of an anophoric process. Therefore, the main goal of this paper is to describe a new species of Corixidea from Brazil, providing diagnosis, photographs of habitus and male genitalia.

\section{MATERIAL AND METHODS}

The specimens analyzed in this study were sampled in the Private Natural Heritage Reserves (RPPN) Monte Alegre ( $3^{\circ} 56^{\prime} 13.56^{\prime}$ 'S, $\left.38^{\circ} 36^{\prime} 48.59^{\prime}{ }^{\prime} \mathrm{W}\right)$, in the municipality of Pacatuba, state of Ceará, Brazil (Figs 1-4). This area is a transition zone of dry forest, locally known as Caatinga, and the Atlantic Forest, and it is located at the Aratanha Mountain Range, whose altitude ranges from 100 to $750 \mathrm{~m}$ a.s.l. (Figs 1-4). Specimens were collected in a forested area located about $200 \mathrm{~m}$ a.s.l. with Winkler extractors. All the specimens were stored in $70 \%$ alcohol and held at the entomological collection of the Museu Paraense Emílio Goeldi (MPEG), Belém, state of Pará, Brazil.

Preparation of male holotype genitalia was made by removing the abdomen of one specimen and clearing it in $10 \% \mathrm{KOH}$ for 24 hours at room temperature. Posteriorly, it was washed in water, then treated in $10 \%$ acetic acid and examined in slides in glycerin. After examination and drawing, the abdomen was stored in microvial with $70 \%$ ethanol with the remaining parts of holotype.

Photographs of habitus and terminalia were taken using a DFC450 camera connected to a Leica M205A stereomicroscope with Planapo 1.0x objective and stacked with Leica Application Suite (LAS) V4.3.

Morphological terminology and abbreviations follow WeIRAUCH et al. (2018) for general morphology and KNYSHOV et al. (2018) for male genitalia.

\section{RESULTS}

\section{Corixidea quaresmai sp. nov.}

(Figs 5-10)

http://zoobank.org/urn:lsid:zoobank.org:act:C3901BBC981F-4F7F-A865-7C6F2EB10DE1

Type material. Holotype $\widehat{\jmath}$, BRAZIL, Ceará: Pacatuba (Reserva Particular do Patrimônio Natural (RPPN) Monte
Alegre, 3'56'04.7'S, 38³6'40.9'W), Carvalho-Filho \& Albuquerque col. (MPEG); Paratypes, $3 \hat{} \lambda$, same data as holotype (MPEG).

Measurements: Male holotype. Total length: 1.23 $\mathrm{mm}$; interocular distance: $0.33 \mathrm{~mm}$; pronotum length: 0.19 $\mathrm{mm}$; pronotum width: $0.57 \mathrm{~mm}$; scutellum length: $0.17 \mathrm{~mm}$; abdominal width: $0.53 \mathrm{~mm}$.

Diagnosis. Distinguished from known Corixidea species in having distal extension of anophoric process parallel and close to the left lateral margin of tergites and elongated process of tergum 8 with distal half pectinate and with a filiform tip (Fig. 8).

Description. Male (Figs 5-7): macropterous, body ovoid. Coloration: general coloration brown, antenna and legs uniformly yellow, abdomen brown. Surface and vestiture: head, pronotum and wing veins with medium-length light brown setae, abdomen densely covered with long, light brown setae, wing cells with distinct cell-like sculpture. Structure: Head: slightly declivent in lateral view, ellipsoid in ventral view, width of eye about $1 / 3$ width of synthlipsis, ocellus about same size to one ommatidium, close to margin of compound eye. Thorax: pronotum trapezoidal, with posterior margin slightly curved posteriorly, scutellum triangular, with rounded tip, metepisternum with posterior margin rounded, blunt metasternal process widened apically, hind coxa with well-developed adhesive pad, tarsal formula 3-3-3, pretarsus with setiform parempodia, arolia present on fore- and midleg. Abdomen. Six visible sterna corresponding to segments 2+3, $4,5,6,7$, and pygophore, equally sclerotized (Fig. 9). Sternum 2 wider than other sterna (Fig. 9). Sternum 7 rectangular and slightly asymmetrical (Fig. 9). Mediotergite 8 asymmetrical, with process insertion on left side (Figs 8, 10). Process of mediotergite $8(\mathrm{mt} 8 \mathrm{p})$ elongated, with widened basal portion perpendicular to distal portion; distal portion elongated with a row of comb-like spines and a filiform projection curved anteriorly (Figs 8, 10). Genitalia (Figs 8-10). Pygophore (pyg) slightly asymmetrical, almost triangular, with rounded apex. Right paramere (rp) elongated, with pointed tip bearing a small pointed projection and a rounded pre-apical process covered with a tuft of small light setae. Left paramere (lp) short and plate-like, about as long as wide. Vesica (v) coiled, tubular and thin, tapering apically, without processes. Anophore (ano) dorsally flattened, tapering distally, and directed to the right lateral margin. Anophoric process (anop) very long, with rounded apex reaching mediotergite 4 and distal extension parallel to left margin of tergites, slightly arched with a row of light setae on left margin.

Etymology. Named in honor of Luís Augusto Quaresma (in memoriam) for his friendship and support with specimens collection. Quaresma passed away in January 2021 but he will always be remembered for his joy, charisma, and happiness.

Distribution (Fig. 1). Brazil (Ceará). 

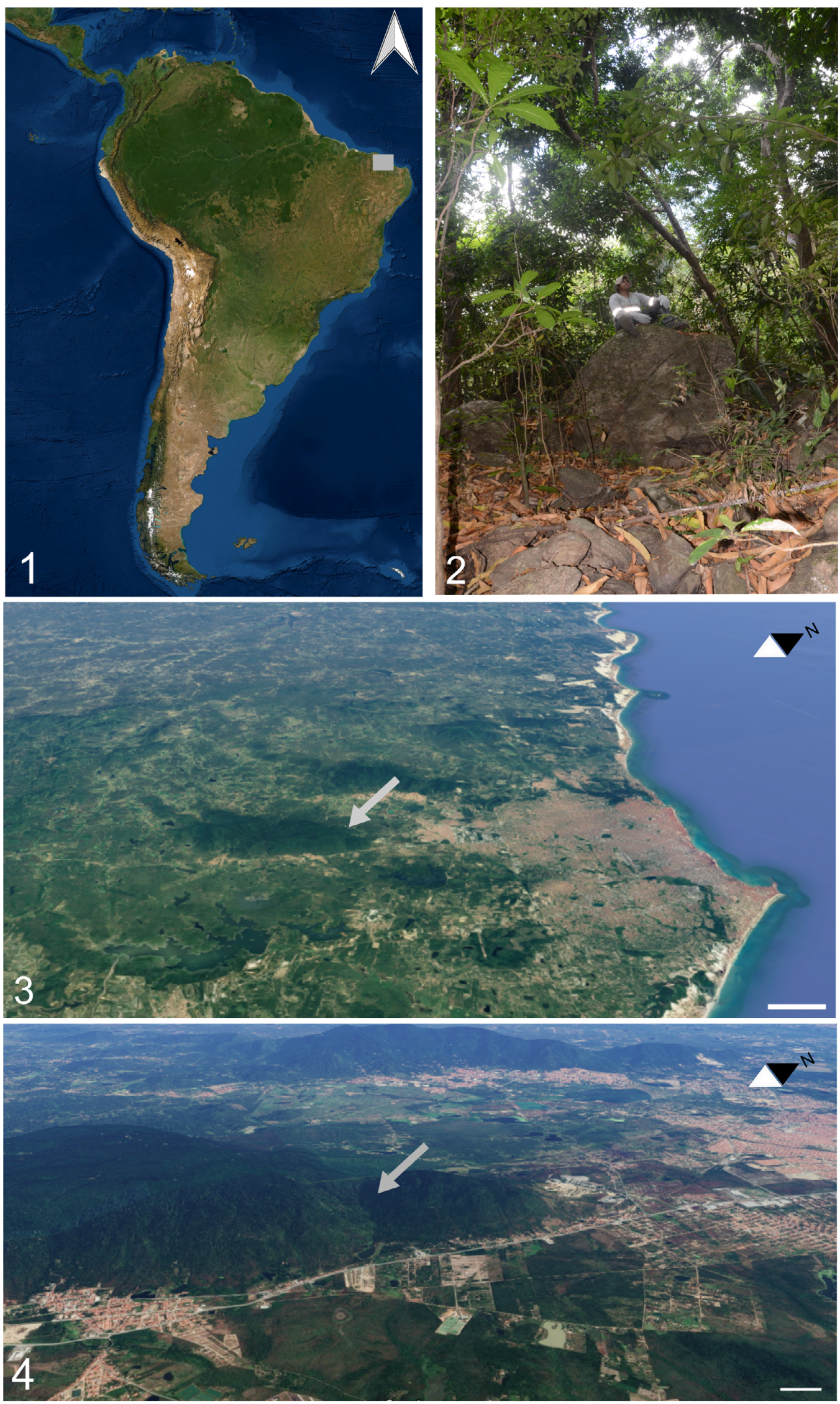

Figs 1-4. Study area:1, satellite image of South America; grey square shows the area where the study area is located; 2 , detail of forest where the typespecimens were collected; 3 , satellite image of region highlighted with a grey square in figure 1 , grey arrow shows the mountainous region where the specimens were collected; 4 , satellite image of the mountainous region, grey arrow shows the sampled site. Scale bars: Fig. $3=5 \mathrm{~km}$, Fig. $4=500 \mathrm{~m}$. 


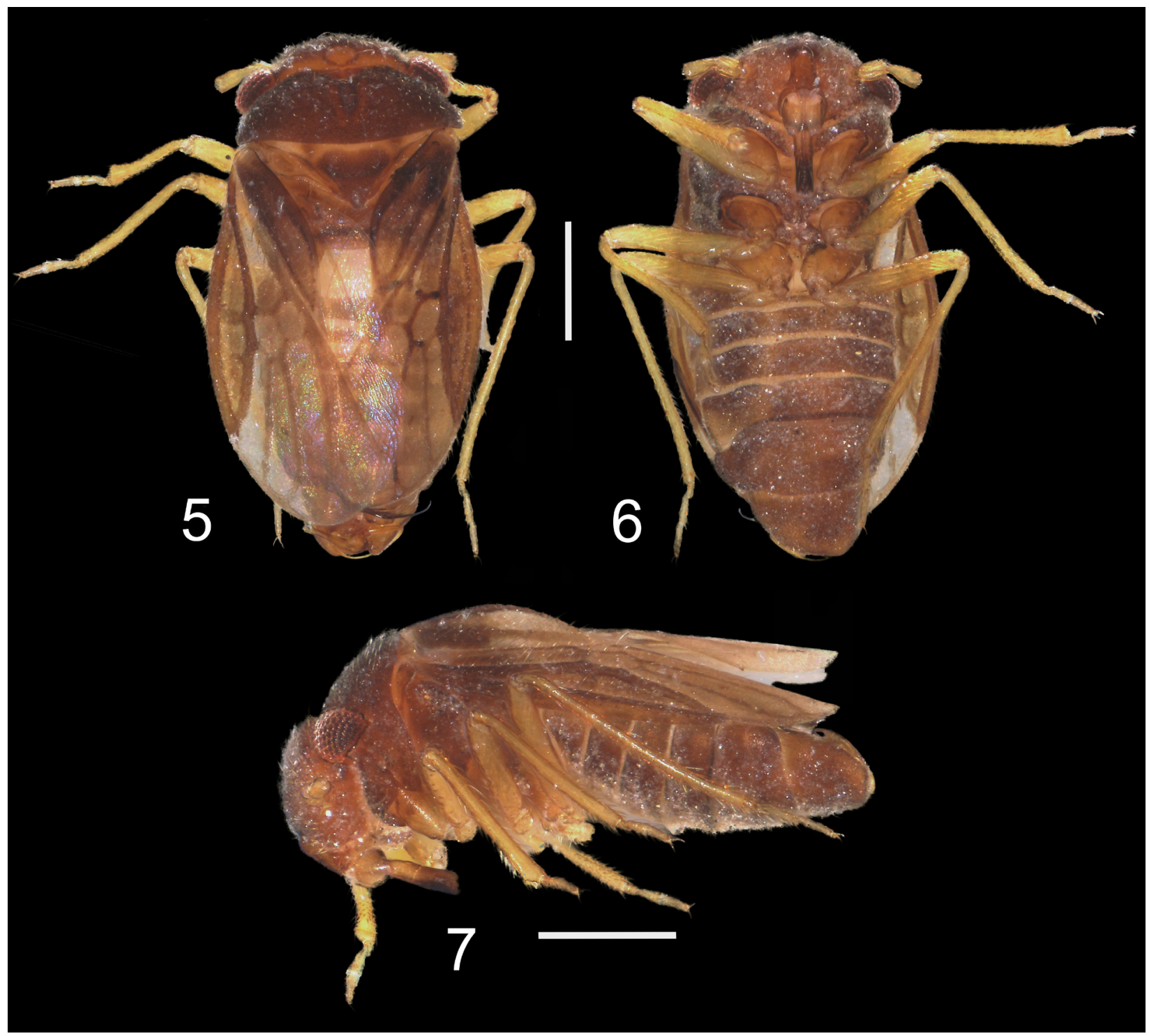

Figs 5-7. Corixidea quaresmai sp. nov., habitus of male holotype: 5, dorsal; 6, ventral; 7, lateral. Scale bars: $0.5 \mathrm{~mm}$.

\section{DISCUSSION}

The genus Corixidea comprises nine described species distributed all around the American subtropic and tropics from southern USA (1 sp.) and Mexico (1 sp.), Caribbean Islands [Cuba (1 sp.), St. Vincent (1 sp.) and Trinidad (3 spp.)] to Panama (1 sp.) and Brazil (1 sp.) (EMSLEY, 1969). The only species previously recorded from Brazil, C. lunigera, was collected in the state of Pernambuco, in the northeast region (Emsley, 1969). Therefore, Corixidea quaresmai sp. nov., also collected in the northeast region, is the second record of this genus from Brazil. According to WeIRAUCH et al. (2018), many undescribed species of Corixidea are known (WeIRAUCH et al., 2018) and it is among the most common genera of Schizopteridae in the leaf litter in other regions of Brazil, such as the Brazilian Amazon (pers. observ.). Therefore, the number of known Brazilian species surely is underestimated, mainly due to a lack of taxonomic studies and efforts to collect specimens.
The new species described herein differs from the other species of Corixidea in having a very long anophoric process anteriorly projected reaching the mediotergite 4, and the process of tergum 8 with a pectinate distal half (Figs 8, 10). A very long anophoric process is also present in Corixidea underwoodi Emsley, 1969 from Trinidad and Tobago and in a Venezuelan specimen that was tentatively identified as the type-species Corixidea lunigera (Reuter, 1891) by McAtee \& Malloch (1925). However, in these two species the anophoric process does not run parallel to abdominal margin. In the Venezuelan specimen pictured by MCATEE \& MALLOCH (1925) the anophoric process is medially placed on the abdomen and in C. underwoodi it is obliquely placed in relation to the lateral abdominal margin. A very long anophoric process is also present in a subgroup composed of some undescribed species classified in the Corixidea crassa species group (KNYSHOV et al., 2019). 

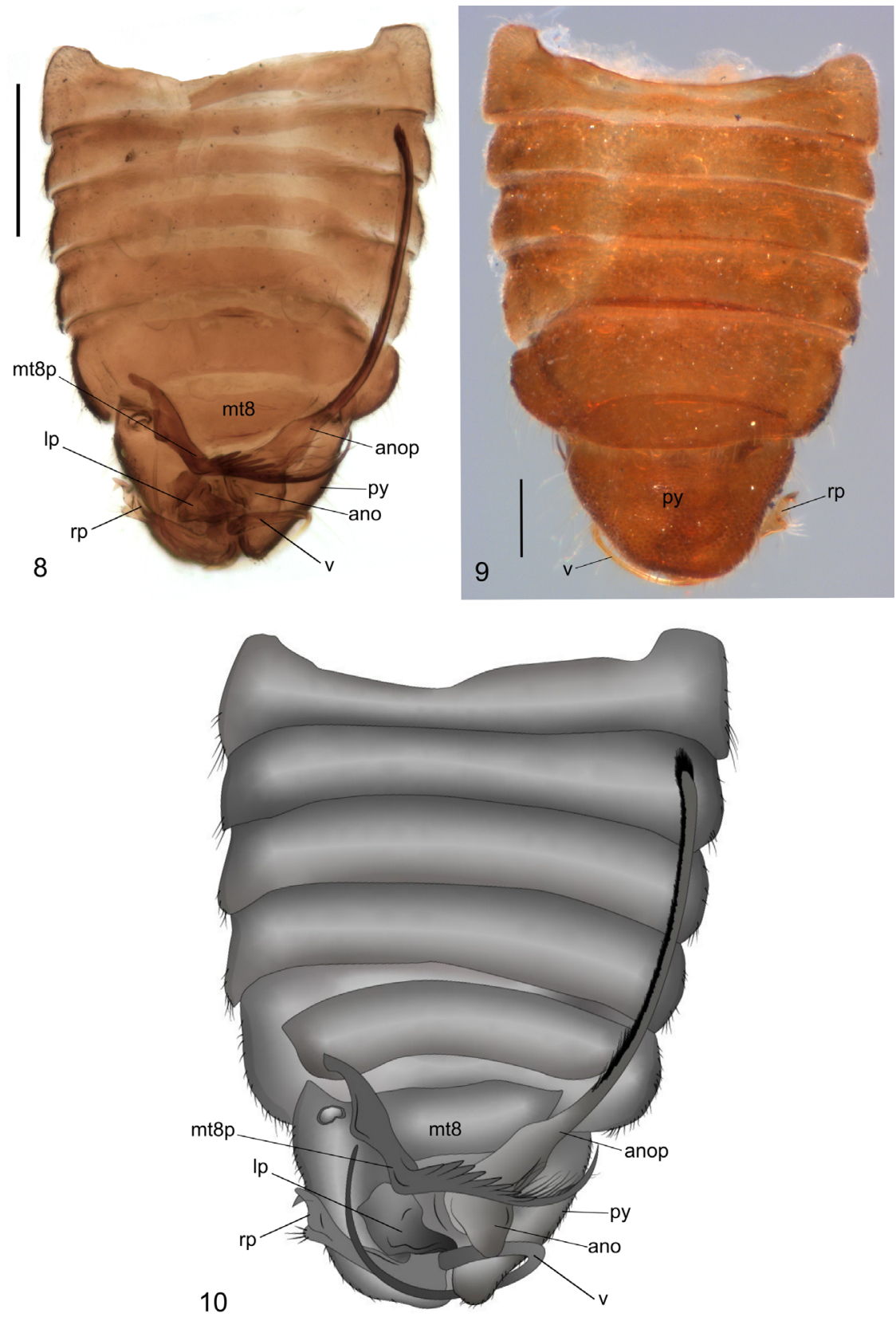

Figs 8-10. Corixidea quaresmai sp. nov., abdomen of male holotype: 8, dorsal; 9, ventral; 10, dorsal (ano, anophore; anop, anophoric process; lp, left paramere; rp, right paramere; $\mathrm{mt} 8$, mediotergite 8 ; mt8p, mediotergite 8 process; py, pygophore; v, vesica). Scale bars: Figs 8, 10, 0.2 mm; Fig. 9, $0.1 \mathrm{~mm}$.

Acknowledgments. The authors thank Lúcia Cunha Castro, owner of the Monte Alegre Reserve, for permitting us to collect on the property. We also thank Célio Moura Neto for his valuable information on the collecting site, and Luís Augusto Quaresma and César A. C. Favacho for their help with specimens collection. We would like to thank Dr. Alistair J. Campbell and Dr. Hein van der Voort for reviewing the English. The first author's travel expenses were funded by the Museu Paraense Emílio Goeldi - Ministério da Ciência, Tecnologia e Inovação. The second author's travel expenses were funded by the Conselho Nacional de Desenvolvimento Científico e Tecnológico - CNPq (CNPq FRAA 140079/2018-1). We also thank the Brazilian Fulbright Commission. Two anonymous reviewers greatly contributed to the improvement of the paper.

\section{REFERENCES}

Almeida, F. R. A.; Carvalho-Filho, F. S. \& Fernandes, J. A. M. 2019a. A new species of Hypsohapsis (Heteroptera: Schizopteridae: Hypselosomatinae) from the Brazilian Amazon. Zootaxa 4551(4):463470.

Almeida, F. R. A.; Carvalho-Filho, F. S.; Castro, H. A. \& Fernandes, J. A. M. 2019b. Two new species of Hoplonannus (Heteroptera: Schizopteridae: Schizopterinae) from the Brazilian Amazon. Zootaxa 4658(2):355-367.

Almeida, F. R. A.; Carvalho-Filho, F. S.; Knyshov, A. \& Fernandes, J. A. M. 2020. Voragocoris weirauchae sp. n. (Heteroptera: Schizopteridae: Schizopterinae), a further minute litter bug species from Brazil. Zootaxa 4729(1):138-144. 
Emsley, M. G. 1969. The Schizopteridae (Hemiptera: Heteroptera) with the descriptions of new species from Trinidad. Memoirs of the American Entomological Society 25:1-154.

Hoey-Chamberlain, R. \& Weirauch, C. 2016. Two new genera of bigeyed minute litter bugs (Hemiptera, Schizopteridae, Hypselosomatinae) from Brazil and the Caribbean. Zookeys 640:79-102.

Knyshov, A.; Leon, S.; Hoey-Chamberlain, R. \& Weirauch, C. 2016. Pegs, pouches, and spines: Systematics and comparative morphology of the New World litter bug genus Chinannus Wygodzinsky, 1948. Annapolis, Entomological Society of America. 112p.

Knyshov, A.; Hoey-Chamberlain, R. \& Weirauch, C. 2018. Comparative morphology of male genitalic structures in the minute litter bugs Dipsocoromorpha (Insecta: Hemiptera: Heteroptera). Journal of Morphology 279:1480-1517.

Knyshov, A.; Hoey-Chamberlain, R. \& Weirauch, C. 2019. Hybrid enrichment of poorly preserved museum specimens refines homology hypotheses in a group of minute litter bugs (Hemiptera: Dipsocoromorpha: Schizopteridae). Systematic Entomology 44(4):985995.

McAtee, W. L. \& Malloch, J. R. 1925. Revision of bugs of the family Cryptostemmatidae in the collection of the United States National Museum. Proceedings of the United States National Museum 67:1-42.

Reuter, O. M. 1891. Monographia Ceratocombidarum orbis terrestris. Acta Societatis Scientiarum Fennicae 19:1-28.
Schuh, R. T. \& Weirauch, C. 2020. Schizopteridae. In: Schuh, R. T. \& WeIRAUCH, C. eds. True bugs of the World (Hemiptera: Heteroptera). Classification and Natural History. 2ed. Manchester, Siri Scientific Press, Monograph Series Volume 8, p. 297-301.

Silveira, D. D.; Barcellos, A. \& KNyshov, A. 2019. Hoplonannus australis sp. nov. (Hemiptera, Schizopteridae): amended diagnosis of the genus and first record from South America. Zootaxa 4568(2):394-400.

Weirauch, C. 2012. Voragocoris schuhi, a new genus and species of neotropical Schizopterinae (Hemiptera: Heteroptera: Schizopteridae). Entomologica Americana 118(1):285-294.

Weirauch, C. \& Fernandes, J. A. M. 2015. The minute litter bugs (Dipsocoromorpha). In: Panizzi, A. R. \& GraZia, J. eds. True bugs (Heteroptera) of the Neotropics. Rotterdam, Springer. v.2, p. 99-112.

Weirauch, C. \& ŠTYs, P. 2014. Litter bugs exposed: phylogenetic relationships of Dipsocoromorpha (Hemiptera: Heteroptera) based on molecular data. Insect Systematics \& Evolution 45:1-20.

Weirauch, C.; Hoey-Chamberlain, R. \& Knyshov, A. 2018. Synopsis of Schizopteridae (Hemiptera, Heteroptera, Dipsocoromorpha) from the United States, with description of seven new species from the US and Mexico. Zookeys 796:49-82.

Weirauch, C.; Knyshov, A. \& Hoey-Chamberlain, R. 2020. Four new genera of Schizopteridae (Hemiptera: Heteroptera) from the Afrotropical and Neotropical regions. Zootaxa 4768(1):95-111. 